that they imply that good sense and the application of sufficient resources will somehow make the development problem come right. It seems at least as likely that some of the developing countries will find themselves incorrigibly beyond the pale of the development assistance richer governments are politically able to provide. That is a dreadful prospect, but no less real on that account.

Even King and Schneider would be more convincing if they were more explicit about the accomplishment of their worthy goals. It is right to say, for example, that the management of a world consisting of a host of small and nationalistic nations will complicate the management of the global environment, but insufficient then to discuss the difficulties of making democratic systems work. There are one or two dark hints, perhaps unintended, that everything would be simpler if stability were weighed together with democracy as social goals - and if the media were somehow made more responsible. The trouble is that if apocalypse is a present danger, it will have to be avoided in the real and imperfect world. King and Schneider, like the Club of Rome itself, exude something of the belief that, if only they were trusted with putting things to rights, they would manage well enough. But that has become an unpopular way of solving even important problems. And they are unlikely to be given the chance.

\section{AIDS talk goes on}

Next year's international gathering on AIDS is to continue, but to what end?

THE eighth international AIDS conference, which has been in doubt since its Harvard University organizers refused to hold it at Boston in protest at US immigration policy barring HIV carriers from the United States, is back on track. Max Essex and Jonathan Mann announced on 3 September that the meeting will definitely take place in 1992, either in the Netherlands or Spain. Speaking to some 600 AIDS researchers and activists at Robert Gallo's annual laboratory meeting in Bethesda, Maryland, Mann said that the 'crisis' created by US policy presented an opportunity to reassess the AIDS conference, which attracts approximately 10,000 participants.

The organizers of AIDS 1992 promise a meeting that is more international in focus than past conferences have been. They want to pay more attention to AIDS in developing nations where the epidemic is most serious and less attention to strictly national issues, such as US Food and Drug Administration policy. There is an expectation that the social sciences will also be high on the agenda. These are worthy goals but fail to explain what the conference really accomplishes.

Why, one still asks, would anyone want to hold such a meeting? The following 'objectives' have been put forward. First, the meeting is a forum for new informationa point that can be contested. Second, it is an occasion to foster "literacy about AIDS in the humanistic sense" and, third, the mere sight of 10,000 colleagues in one room provides a sense of 'solidarity' that carries AIDS researchers through to the next conference. It is not immediately clear that such vague objectives justify the millions of dollars that the conference costs, especially when hundreds of AIDS conferences are held around the world all year long with less fanfare and, quite likely, with more significant exchange of information.

\section{Dead Sea Scrolls}

Using a concordance and a computer, scholars have published an unauthorized edition of some of the scrolls.

Biblical scholars in the United States have published an unauthorized but apparently quite reliable version of one of the Dead Sea Scrolls*, thereby breaking the hold a coterie of authorized researchers and their intellectual descendants have had on the ancient writings since their discovery in 1947 in caves in what is now Israel. Using an official concordance produced in the late 1950s (but not circulated until 1988) and a desk top computer called Rabbi, Ben Zion Wacholder and Martin G. Abegg of Hebrew Union College in Cincinnati, Ohio reconstructed the text of Hebrew and Aramaic writings from what is known as Qumran Cave Four.

The text, which can be easily read only by scholars in the field, includes the calendars with festival, lunar and historical data. For instance, there has been a debate about whether the Essenes, a Jewish sect to which Jesus may have belonged, were celibate. Apparently, they were not.

When the scrolls were first discovered, scattered among 11 caves, the right to publish them was assigned by the government of Jordan, which then controlled the caves, to a small group of scholars who were expected to translate the entire opus within a few years. Forty years later, only an estimated 20 percent of the text has been published. It was this slow pace that drove Wacholder to act.

"Frustrated by the realization that at the current rate of publication we shall all be dead when the corpus of the Dead Sea texts becomes available to the world, we began reconstructing the [concordance] as an experiment," he writes. The concordance lists each document in the corpus, each word in it, and the adjacent words in the text so that passages can be assembled like pieces of a puzzle. Wacholder and Abegg expect to publish at least five more fascicles before they are done.

The fact that a small group of scholars has kept such historically important data secret for so long is appalling. If scientific data were at issue, the research community would (and has) rise up in righteous wrath, demanding access. A similar presumption of scholarly access should apply in the humanities as well, and certainly in this case. Although some of the official scholars have complained in the press that the unauthorized publication amounts to theft of data in the concordance, the new publication is a service to scholarship.

*A Preliminary Edition of the Unpublished Dead Sea Scrolls. Biblical Archeological Society, 3000 Connecticut Avenue, NW., Washington, D.C. 20008 